\title{
Fermentation and Digestibility Characteristics of Soybean, Sunflower and Their Mixture Silages
}

\author{
Cüneyt TEMÜR ${ }^{\star 1}$, Mehtap GÜNEY $^{1}$, Sibel ERDOĞAN ${ }^{1}$, Murat DEMİREL ${ }^{1}$
}

${ }^{1}$ Yuzuncu Yil University Faculty of Agriculture Department of Animal Science, Van, TURKEY

Cüneyt TEMÜR, ORCID No: 0000-0001-7952-7566, Mehtap GÜNEY, ORCID No: 0000-0002-0613-3600, Sibel ERDOĞAN, ORCID No: 0000-0003-2640-3871, Murat DEMIREL, ORCID No: 0000-0002-2992-8393

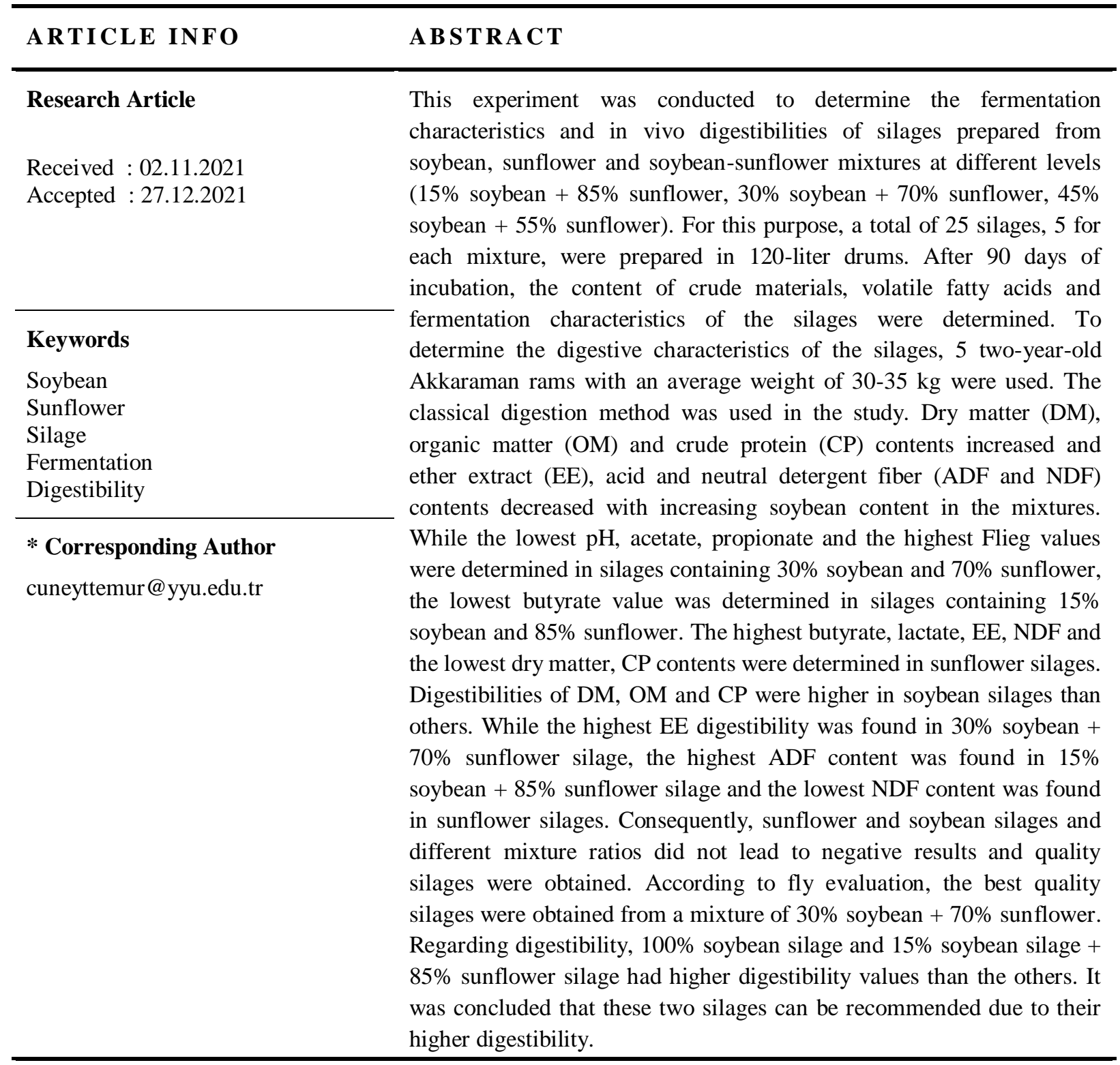

\section{Soya, Ayçiçeği ve Bunların Karışım Silajlarının Fermantasyon ve Sindirilebilirlik Özellikleri}

\author{
MAKALE B İLGİS İ \\ $\ddot{\mathbf{O Z}}$
}




\section{Araştırma Makalesi}

Geliș : 02.11.2021

Kabul : 27.12.2021

\section{Anahtar Kelimeler}

Soya

Ayçiçeği

Silaj

Fermantasyon

Sindirilebilirlik

\section{* Sorumlu Yazar}

cuneyttemur@yyu.edu.tr
Bu çalışma soya, ayçiçeği ve $\% 15$ soya $+\% 85$ ayçiçeği, $\% 30$ soya + $\% 70$ ayçiçeği, $\% 45$ soya $+55 \%$ ayçiçeği karışımı silajlarının fermentasyon ve sindirim özelliklerini belirlemek amaciyla gerçekleştirilmiştir. Bu amaçla her bir karışım için 120 litrelik plastik varillerde 5'er adet olmak üzere toplam 25 adet silaj hazırlanmıştır. 90 günlük inkübasyon sonunda açılan silajların ham besin madde içerikleri ve fermentasyon özellikleri incelenmiştir. Silajların sindirim özelliklerini belirlemek için 5 adet 2 yaşlı, ortalama 30-35 kg ağırlığında Akkaraman erkek toklu kullanılmıştır. Bu hayvanların bakım, besleme, yem tüketimi, gübre toplama, örnekleme ve analiz işlemleri klasik sindirim metodu ile gerçekleştirilmiştir. Karışımlardaki soya miktarı artışına bağlı olarak kuru madde (KM), organik madde (OM) ve ham protein (HP) değerleri artmasına rağmen, ham yağ (HY), ADF ve NDF değerleri düşmüştür. En düşük $\mathrm{pH}$, asetik asit, propiyonik asit ve en yüksek flieg puanı $\% 30$ soya $+\% 70$ ayçiçeği silajlarında elde edilmiştir. En düşük bütirik asit değeri ise \%15 soya $+\% 85$ ayçiçeği karışımında tespit edilmiştir. En yüksek bütirik asit, laktik asit, HY, NDF ve en düşük KM, HP değerleri ayçiçeği silajlarında belirlenmiştir. Soya silajının KM, OM ve HP sindirilebilirlikleri diğer silajlardan daha yüksek bulunmuştur. \%30 soya $+\% 70$ ayçiçeği karışım silajında $\mathrm{HY}$ sindirimi en yüksek olurken, en yüksek ADF sindirimi $\% 15$ soya $+\% 85$ ayçiçeği karışımında ve en düşük NDF sindirimi ayçiçeği silajında gerçekleşmiştir. Sonuç olarak ayçiçeği ve soya silajı ve farklı karışım oranları olumsuz sonuçlara yol açmamış ve kaliteli silajlar elde edilmiştir. Flieg skorlamasına göre en kaliteli silajlar $\% 30$ soya $+\% 70$ ayçiçeği karışımından elde edilmiştir. Sindirilebilirlik açısından \%100 soya silajı ve \%15 soya $+\% 85$ ayçiçeği silajının diğerlerine göre daha yüksek sindirilebilirlik değerlerine sahip olduğu, bu nedenle bu iki silajın tavsiye edilebileceği sonucuna varılmıştır.

\section{Introduction}

In regions where winters are long, the necessity of feeding animals for the duration of the cold season has necessitated the development of methods of preservation. The method of ensiling is becoming more widespread. Various applications have been reported to improve the quality and digestibility of silage during ensiling. (Kilic, 1986; Etgen et al., 1987).

Sunflowers are preferred especially in semi-arid climatic regions because they develop earlier, are more cold and drought resistant and give higher yields than maize. Sunflowers have $2 / 3$ of the total digestible nutritional value of maize. Sunflower silage is less preferred by animals than corn silage. Although sunflower oil increases the amount of milk fat, it decreases the amount of milk. However, it can be considered an advantage that dairy cows fed sunflower silage (SF) have more unsaturated fatty acids in milk fat (McGuffey and Schingoethe, 1980). To eliminate these disadvantages of SF, early harvesting and ensiling with ensiling agents that have higher dry matter is suggested (DM). In this way, the problems arising from a low DM, high lignin and oil content can also be solved (Denek et al., 2004). Soybean silage (SBs) has higher nutritional value than pea silage and lower than vetch silage (Mustafa and Seguin, 2003).

When SBs is fed alone, it is not properly utilised by animals due to its unpleasant 
odour, free ammonia content and butyric acid (BA). To achieve proper fermentation, easily degradable carbohydrate sources must be added. Therefore, combination with silage crops or molasses is recommended (Brown, 1999; Blaunt et al., 2006). Ensiling soybeans with other silage crops not only increases the crude protein content (CP) of the silage, but also increases the energy content and palatability of SB (Kilic, 1986; Undersander, 1999). Although soybeans and sunflowers can be ensiled alone, they have some disadvantages, both in terms of silage quality and consumption by animals.

It is believed that making silage by mixing these two crops grown in the same period can eliminate these disadvantages. For this reason, this study was carried out to determine the ensiling properties and nutrient digestibility of sunflower, soybean and sunflower-soybean mixed silages produced at different levels.

\section{Material and Method}

Sunflowers and soybeans harvested early were used as silage. Sunflower, soybean and sunflower-soybean mixtures feeds were adjusted in different ratios: $15 \%$ soybean $+85 \%$ sunflower (15SB85SF), 30\% soybean $+\% 70$ sunflower (30SB70SF) and $45 \%$ soybean $+55 \%$ sunflower (45SB55SF), based on fresh material. The prepared mixtures were placed in 25 120-liter plastic drums with 5 replicates for each group and their mouths tightly sealed. A small hole was drilled in the top of the barrels to allow the silage liquid to drain. The barrels were then turned upside down and placed to ferment. 90 days later, the barrels were opened and samples were taken for chemical analysis. Table 1 shows the chemical composition of the fresh material.

The $\mathrm{pH}$ values of the silages were immediately measured in samples according to Hart and Horn (Hart and Horn, 1987) after taking samples from the top, middle and bottom of the barrels. The remaining silage fluid was then filtered through Whatman 54 paper, centrifuged, and stored at $-20^{\circ} \mathrm{C}$. Lactic acid (LA), acetic acid (AA), propionic acid (PA), and butyric acid (BA) were analyzed in the silage liquids using high-performance liquid chromatography (Muck and Dickerson, 1988).

In vivo digestion was performed to determine the digestibility of the silages. 5 Akkaraman rams aged 2 years with an average body weight of 30-35 kg were used. Animal husbandry and feeding, feed intake, and fecal collection and analysis were performed as described by Bulgurlu and Ergul (1978).

Dry matter, CP, EE and ash of silages and manures were determined according to AOAC (1990). ADF and NDF were determined according to Van Soest et al. (1991). Statistical analyzes were performed using PROC GLM in SAS/STAT (2007) for all data analyzes. Mean treatment differences were determined by Duncan's multiple range tests with a level of statistical differences of $5 \%$.

\section{Results}

Table 1 displays the nutrient composition of silages of sunflower, soybean and sunflower-soybean mixtures before and after ensiling. It was found that very little nutrient loss occurred with the water from the silo. The highest contents of DM, OM and CP were 
found in SBs, while EE, ADF and NDF were found in SFs. As a result of this situation, the contents of DM, OM and $\mathrm{CP}$ increased when the amount of soybean in the mixture was increased; EE, ADF and NDF decreased.

Table 1. Nutrient compositon of sunflower, soybean and sunflower-soybean green herbages before and after ensiling (DM\%).

Tablo 1. Ayçiçeği, soya ve ayçiçeği-soya yeşil otlarının silolama öncesi ve sonrası ham besin maddesi içerikleri (\%KM)

\begin{tabular}{lcccccccccc}
\hline & \multicolumn{2}{c}{ SF } & \multicolumn{2}{c}{ SB } & \multicolumn{2}{c}{ 15SB85SF } & \multicolumn{2}{c}{ 30SB70SF } & \multicolumn{2}{c}{ 45SB55SF } \\
\hline & be & ae & be & ae & be & ae & be & ae & be & ae \\
\hline DM & 22.98 & 22.55 & 32.23 & 31.32 & 23.72 & 23.35 & 26.08 & 25.60 & 28.17 & 27.30 \\
OM & 80.51 & 80.83 & 85.56 & 85.21 & 81.46 & 80.80 & 81.97 & 81.54 & 83.73 & 83.22 \\
CP $^{1}$ & 2.31 & 2.22 & 4.94 & 4.79 & 2.61 & 2.57 & 2.59 & 2.54 & 4.01 & 3.86 \\
EE & 14.25 & 14.08 & 7.69 & 7.54 & 12.76 & 12.61 & 11.18 & 11.14 & 10.87 & 10.55 \\
ADF & 38.89 & 38.20 & 37.49 & 36.80 & 37.11 & 36.52 & 37.68 & 37.44 & 37.91 & 37.74 \\
NDF & 51.08 & 50.56 & 49.51 & 49.98 & 50.12 & 49.89 & 48.72 & 48.42 & 50.06 & 49.90 \\
\hline
\end{tabular}

:fresh material

be:before ensiling, ae:after ensiling

15SB85SF: $15 \%$ soybean forage+ $85 \%$ sunflower forage

30SB70SF: $30 \%$ soybea forage $+70 \%$ sunflower forage

45SB55SF: $45 \%$ soybea forage $+55 \%$ sunflower forage

The fermentation characteristics are listed in Table 2. The highest $\mathrm{pH}$ and $\mathrm{AA}$ values were in 45SB55SF, flieg values in 30SB70SF, BA, PA and LA values in SFs $(\mathrm{P}<0.05)$. The lowest $\mathrm{pH}$, AA and PA values were in 30SB70SF, flieg values and LA in 45SB55SF silages $(\mathrm{P}<0.05)$.

Digestibility values are shown in Table 2 . The highest dry matter digestibility (DMD), organic matter digestibility (OMD), crude protein digestibility (CPD) and neutral detergent fiber digestibility (NDFD) values were obtained in SBs. The highest digestibility of ether extract (EED) was obtained in 30SB70SF and digestibility of acid detergent fiber (ADFD) in 15SB85SF silages $(\mathrm{P}<0.05)$.

The lowest values of DMD, OMD, CPD, ADFD and NDFD were determined in SF while EED values were determined in SB and 45SB55SF $(\mathrm{P}<0.05)$. As shown in Table 1 and Table 2, the digestibility values of SF decreased with minimum nutrient content and flight point. To address this situation, digestibility was increased as a function of decreasing SF ratio in the mixtures. 
Table 2. Nutrient composition digestibility and fermentation properties of sunflower, soybean and sunflower-soybean mixture silage at different ratios

Tablo 2. Farklı oranlarda ayçiçeği, soya ve ayçiçeği-soya karışımı silajlarının besin madde sindirilebilirliği ve fermentasyon özellikleri

\begin{tabular}{lllccc}
\hline & SF & SB & 15SB85SF & 30SB70SF & 45SB55SF \\
& $\bar{X}_{ \pm} \mathrm{S} \overline{\mathrm{X}}$ & $\overline{\mathrm{X}}_{ \pm} \mathrm{S} \overline{\mathrm{X}}$ & $\overline{\mathrm{X}}_{ \pm} \mathrm{S} \overline{\mathrm{X}}$ & $\overline{\mathrm{X}}_{ \pm} \mathrm{S} \overline{\mathrm{X}}$ \\
\hline $\mathrm{5}$ & \multicolumn{5}{c}{ Fermentation Patterns } \\
\hline $\mathrm{pH}$ & $4.32 \pm 0.06 \mathrm{bc}$ & $4.48 \pm 0.06 \mathrm{~b}$ & $4.16 \pm 0.06 \mathrm{~cd}$ & $4.04 \pm 0.06 \mathrm{~d}$ & $4.82 \pm 0.06 \mathrm{a}$ \\
Flieg & $77.45 \pm 2.37 \mathrm{~b}$ & $87.51 \pm 2.37 \mathrm{a}$ & $90.06 \pm 2.37 \mathrm{a}$ & $92.94 \pm 2.37 \mathrm{a}$ & $71.38 \pm 2.37 \mathrm{~b}$ \\
Acetic acid & $4.10 \pm 0.31 \mathrm{~b}$ & $3.07 \pm 0.31 \mathrm{c}$ & $3.38 \pm 0.31 \mathrm{bc}$ & $2.56 \pm 0.33 \mathrm{c}$ & $5.05 \pm 0.31 \mathrm{a}$ \\
Butyric acid & $0.69 \pm 0.14 \mathrm{a}$ & $0.21 \pm 0.14 \mathrm{~b}$ & $0.09 \pm 0.14 \mathrm{~b}$ & $0.19 \pm 0.15 \mathrm{~b}$ & $0.25 \pm 0.14 \mathrm{~b}$ \\
Propionic & $1.31 \pm 0.15 \mathrm{a}$ & $0.55 \pm 0.15 \mathrm{~b}$ & $0.60 \pm 0.15 \mathrm{~b}$ & $0.42 \pm 0.16 \mathrm{~b}$ & $0.61 \pm 0.15 \mathrm{~b}$ \\
Lactic acid & $7.99 \pm 0.42 \mathrm{a}$ & $5.87 \pm 0.42 \mathrm{~b}$ & $5.91 \pm 0.42 \mathrm{~b}$ & $5.62 \pm 0.42 \mathrm{~b}$ & $4.90 \pm 0.42 \mathrm{~b}$ \\
\hline \multicolumn{5}{c}{ Digestibility } \\
\hline DM & $54.10 \pm 1.28 \mathrm{c}$ & $65.21 \pm 1.28 \mathrm{a}$ & $60.21 \pm 1.28 \mathrm{~b}$ & $60.02 \pm 1.28 \mathrm{~b}$ & $61.34 \pm 1.28 \mathrm{~b}$ \\
OM & $55.53 \pm 1.07 \mathrm{c}$ & $68.28 \pm 1.07 \mathrm{a}$ & $63.54 \pm 1.07 \mathrm{~b}$ & $60.97 \pm 1.07 \mathrm{~b}$ & $63.55 \pm 1.07 \mathrm{~b}$ \\
$\mathrm{CP}$ & $51.94 \pm 1.56 \mathrm{c}$ & $78.89 \pm 1.56 \mathrm{a}$ & $60.27 \pm 1.56 \mathrm{~b}$ & $61.84 \pm 1.56 \mathrm{~b}$ & $63.14 \pm 1.56 \mathrm{~b}$ \\
EE & $95.34 \pm 0.38 \mathrm{~b}$ & $93.97 \pm 0.38 \mathrm{c}$ & $96.31 \pm 0.38 \mathrm{~b}$ & $97.94 \pm 0.38 \mathrm{a}$ & $94.08 \pm 0.38 \mathrm{c}$ \\
ADF & $47.09 \pm 1.30 \mathrm{c}$ & $54.27 \pm 1.30 \mathrm{ab}$ & $55.99 \pm 1.30 \mathrm{a}$ & $51.72 \pm 1.30 \mathrm{~b}$ & $51.16 \pm 1.30 \mathrm{~b}$ \\
NDF & $47.45 \pm 1.38 \mathrm{~cd}$ & $54.62 \pm 1.38 \mathrm{a}$ & $53.01 \pm 1.38 \mathrm{ab}$ & $49.42 \pm 1.38 \mathrm{c}$ & $53.74 \pm 1.38 \mathrm{ab}$ \\
\hline
\end{tabular}

a,b,c,d,e: Differences among values in the same line bearing different letters are significant $(\mathrm{P}<0.05)$.

\section{Discussion and Conclusion}

In studying the nutrient composition of silages made from sunflower and sunflowersoybean mixtures, it was found that as the proportion of soybean in the mixture increased, the relative amounts of $\mathrm{DM}, \mathrm{OM}, \mathrm{CP}$, and $\mathrm{EE}$ decreased in proportion to the decreasing amount of sunflower EE (Table 2).

In a similar study, Carneiro et al. (1986) reported that the DM of silages increased when soybean was added to maize. Evangelista (1986) shared that the addition of soybeans improved the nutritional value and quality of mixed silages of corn and soybeans. For example, when soybean content in the mixture was $30 \%, \mathrm{CP}$ of corn and sorghum silage increased from 6.5 to $8.5-9.0 \%$. In the results of our study, $\mathrm{CP}$ values of silages with $45 \%$ soybean addition were increased from 2.31 to 3.86\%. In a study by Serbester et al. (2015), the nutrient composition and in vitro digestibility of silages made from a maize mixture SB were determined and it was found that when the soybean content in the mixture was increased, the $\mathrm{pH}, \mathrm{CP}, \mathrm{EE}$ of the mixture increased but NDF and ADF decreased.

The results in Table 2 on fermentation characteristics show that the quality of silage is not affected by the addition of soybeans to sunflower, on the contrary, the addition of soybeans increases the quality of silage. Thus, it was found that the fly value increased especially at 30SB70SF. Although it was reported that high protein content and low readily fermentable carbohydrate content increased silage $\mathrm{pH}$ (Cerci et al., 1997), this was not found 
in our study and in the study of Demirel et al. (2009). In fact, CP content was reported to increase in mixed silages with soybean content of 30-50\%, but according to the results of $\mathrm{pH}$ and lactic acid, there is no need to use high energy additives (Lima et al., 2010). Regarding the quality criteria $\mathrm{pH}, \mathrm{AA}, \mathrm{PA}, \mathrm{BA}$ and LA, it was found that the mixture ratios used had no negative effect on the fermentation potential. The $\mathrm{pH}$ values observed in this study were within the range of required optimum silage fermentation (Alcicek and Ozkan, 1997). Evangelista (1986) and Zago (1985) reported that $\mathrm{pH}$ and lactic acid content were similar in corn silages and silages containing 20\%, 30\%, 35\%, 40\% and 50\% soybean and that fermentation characteristics did not change with increasing soybean content in the mixture. In this study, BA, PA and LA were also not affected by the addition of soybean, but only 45SB55SF silages reduced the fly value and increased the value of AA ( $\mathrm{P}<0.05)$. Lima et al (2010) reported that combined ensiling of sorghum and soybean resulted in better silage quality than either sorghum or soybean alone.

It is suggested that the reason for the digestion results reported in Table 2 may be that the lignin structure of sunflower diluted with soybean is increased by up to $17 \%$ (McGuffey and Schingoethe, 1980). However, Demirel et al. (2009) reported that the reason for the increase in digestion was due to other nutrients facilitating digestion and not the increased CP and EE with the addition of soybean to corn. However, several researchers reported that no differences were found between the DM, CP and ADF digestibilities of corn and cornsoybean silages (Murphy et al., 1984) and that the addition of $40 \%$ soybean had no effect on in vitro DM digestion of silages (Lima et al., 2010). Carneiro et al. (1982) found that CP digestibility of corn-soybean silages with $20 \%$ and $40 \%$ soybean content was higher than that of corn silages. Serbester et al. (2015) reported that depending on the increase of soybean content in the mixture, in vitro DMD and NDFD were increased.

In conclusion, sunflower and soybean silage and different mixture ratios did not cause negative results and silages of high quality were obtained. According to fly evaluation, the best quality silages were obtained from a mixture of $30 \%$ soybean $+70 \%$ sunflower. Regarding digestibility, $100 \%$ soybean silage and $15 \%$ soybean silage $+85 \%$ sunflower silage had higher digestibility values than the others. Therefore, it was concluded that these two silages can be recommended due to their higher digestibility.

\section{References}

A.O.A.C., 1990. Association of official analytical chemistry. Official Methods of Analysis, 15th,Vol:1, Washington,D.C.

Alcicek, A. and Ozkan K., 1997. Determination of Silage Quality with Physical and Chemical Methods in Silages. Bursa Uladag University, Bursa, Turkey, pp: 241-246.

Bulgurlu, Ş.and Ergül, M., 1978. Analyses methods of physical, chemical and biological of feeds. Ege University, Issue Number: 127,176p

Blaunt, ARS., Wright, DL., Sprenkel, RK., Hewitt, TD. and Myer, RO., 2006. Forage soybeans for grazing, hay and silage. University of Florida IFAS Extension, SSAGR-180. http://edis.ifas.ufl.edu/pdffiles/AG/AG18400.pdf.

Brown, C., 1999. Soybeans as a forage crop. 
http://www.omafra.gov.on.ca/english/crops/facts/soybean_forage.htm.

Carneiro, AM., Rodriguez, NM., Sanches, R.L and Socorro, EP., 1982. Consumption and "apparent" digestibility of mixing ensilages of maize and annual soyabean. Arq. Bras. Med. Vet. Zootec.nia, Belo Horizonte, n. 34, v. 2; p. 397-408. ISSN 01020935. doi: $10.1590 / \mathrm{S} 0102$

Cerci, İH., Sahin, K., Talat, G. and Tatl, P., 1997. 'Determination of the Quality of Silages Made at Different Ratios Using Maize and Alfalfa'. Farklı Oranlarda Silajlık Misır ve Yonca Kullanılarak Yapılan Silajların Kalitesinin Belirlenmesi. Turkey 1. Silage Congress, Hasat publishing, 105-113, Bursa.

Demirel, M., Celik, S., Temur, C., Guney, M. and Celik, S., 2009. Determination of fermentation properties and digestibility characteristics of combination of cornsoybean and corn silages. J.Anim. Vet. Adv., 8 (4): 711-714

Denek, N., Can, A. and Tufenk, Ş., 2004. The effects of different additives on silage quality and digestibility of corn, sorghum and sunflower plants. Harran University Agriculture Faculty Journal, 8 (2): 1-10

Evangelista, AR., 1986. Ensiling sorghum and corn with soybean. Lavras: ESAL, 1986b. 19 p. ESAL. Boletim Técnico, 8.

Etgen, WM., James, RE. and Reaves, PM., 1987. Dairy Cattle Feeding and Management. John Wiley and Sons, Inc., New York.

Hart, SP. and Horn FP., 1987. Ensiling characteristics and digestibility of combinations of turnips and wheat straw. J. Anim. Sci., 64:1790-1800. http://jas.fass.org/cgi/reprint/64/6/1790.pdf

Kilic, A., 1986. Silage . Bilgehan Printing House. İzmir, Turkey 350 p.

Kiliç A., Yalçin S. and Yilmaz, A., 2000. Improvements, can be make, in the ruminant roughouge resources,. TUYEM 5. International Feed Convention and Feed Exhibition 1-2 May 2000. Antalya, Turkey

Lima, R., Lourenco M., Díaz RF., Castro A. and Fievez V., 2010. Effect of combined ensiling of sorghum and soybean with or without molasses and lactobacilli on silage quality and in vitro rumen fermentation. Animal Feed Science and Technology 155; 122131

Martin, LCT., Garcia, R. and Silva, JFC., 1983. Effect of corn-soyabean mixtures on silage quality. Brazilian J. of Anim. Sci., 12(3) : 562-575.

McGuffey, RK. and Schingoethe J., 1980. Feeding Value of a High Oil Variety of Sunflowers as Silage to Lactating Dairy Cows. J. Dairy Sci. 63:1109-1113.

Muck, RE. and Dickerson, JT., 1988. Storage temperature effects on proteolysis in alfalfa silage. Transactions of the American Soc. of Agr. Engin., 31:1005-1009.

Murphy, WM., Welch, JG., Palmer, RH., Gilman, BH., Albers, CW. and Dugdale, T., 1984. Digestibilities of silages made from corn interplanted with soybean or fababean. J. Dairy Sci., 67:1532-1534. http://jds.fass.org/cgi/reprint/67/7/1532

Mustafa, AF. and Seguin, P., 2003. Effects of maturity on ensiling characteristics and ruminal nutrient degradability of oat silage. Archives of Animal Nutrition. 57:347-358..

S.A.S., 2007. SAS ${ }^{\circledR}$ User's Guide: Statistics, Version 8. SAS Institute Inc., Cary, NC.

Serbester, Y., Akkaya, MR., Yücel, C. and Gorgulu, M., 2015. Comparison of yield, nutritive value, and in vitro digestibility of monocrop and intercropped corn-soybean silages 
cut at two maturity stages. Ital. J. Anim. Sci. vol.14:3636

Undersander, D., 1999.Soybeans for Hay or Silage.

http://www.uwex.edu/ces/forage/pubs/SOYBNFOR.html

Van Soest, PJ., Robertson, JB. and Lewis, BA., 1991. Methods of dietary fiber, neutral detergent fiber, and nonstarch polysaccharides in relation to animal nutrition. J. Dairy Sci. 74:3583-3597. http://jds.fass.org/cgi/reprint/74/10/3583.

Zago, CP., Obeid, JA. and Gomide, JA., 1985. Performance of steers fed with joined ensilages of maize (Zea mays L.) with annual soyabean (Glycine max L.). Brazilian J. of Anim. Sci., Viçosa, v. 14, n. 4, p. 510-514. 